\title{
Tutkimusmatkailijat ihmemaassa
}

Elettiin pimeää, hidasliikkeistä vuosisataa. Pimeässä, hidasliikkeisessä maassa oli kerran pieni, mutta kiinnostunut tutkimusmatkailijajoukko (n. 19 henkilöä), joka halusi tutkia tuntemattomia polkuja ja maanosia.

Maassa oli myös pirteä Rahapussiporukka, joka oli saanut uuden, kauniin rahapussin ja nyt nyörin pitelijät odottelivat tutkimusmatkailijoilta hyviä ehdotuksia siitä, minne tulisi matkustaa ja mitä silloin voisi löytää. Innostaakseen heitä Rahapussiporukka oli kirjoittanut toivomuslistan, josta piti selvitä minkälaista matkaa toivottiin, minkälainen matkan tulisi olla, jotta pussin nyörit avautuisivat. Tosin Rahapussiporukka ei ollut lukenut matkustami en historiasta paljonkaan - ainakin näytti siltà, koska he olivat käsittäneet että Jatkuva matkustaminen oli sama asia kuin Aikuisten matkat.

Tutkimusmatkailijat kuitenkin arvelivat, että kyllä ne siitä... kunhan vähän paneutuvat niihin lukuisiin muiden, ja juuri näiden tutkimusmatkailijoiden ja maanosien kartoittajien kirjoittamiin selostuksiin ja mietteisiin, joita saa halvallakin tuon valtion omasta kirjapainosta. Ja niin ne 19 tutkimusmatkailijaa jättivät reittisuunnitelmansa Rahapussiporukalle. Monen suunnitelma ei kiinnostanut Rahapussinvartioita alkuunkaan, mutta ainakin 6 heistä sai mahdollisuuden vielä tarkentaa reittisuunnitelmaansa - tosin tehtävälle ei annettu kovin paljon aikaa; Rahapussiporukan mielestä joululoma oli siihen juuri sopivan pituinen aika.

Rahapussiporukan sanansaattaja lähetti siis kuudelle tutkimusmatkailijalle sanoman, jossa kirpeän leikkisästi neuvottiin ja kerrottiin, mitä tutkimusmatkailijan piti suunnitelmastaan ajatella. Mutta nuo kuusi tutkimusmatkasta kiinnostunutta tekivät tietenkin, aivan kuten pyydettiin, vielä selvemmin, mielestänsä vielä varmemman ja kohteiltaan vielä kiinnostavamman ja tuloksekkaamman reittisuunnitelman - olivathan he kaikki monta kertaa matkanneet ja saaneet siitä diploomin ja tiesivät mitä tekivät. Niin he sitten jäivät (matkakamppeet kainalossa) aika iloisina odottelemaan reittisuunnitelman hyväksymistä.
Sanansaattajan ääni oli pirteä ja helisi kuin pussissa kilahtelevat taalat.

- Olisihan sen sinun reittisuunnitelmasi voinut hyväksyäkin, mutta päätimme Rahapussiporukassa, että lakaisemme pöydän puhtaaksi.

- Puhtaaksi?, hämmästeli tutkimusmatkailija. - Miten niin, puhtaaksi?

- No, kas kun oikeastaan me halusimme Ryhmämatkan reittisuunnitelman - kokonaisen matkaohjelman! Ei yksityismatkoja.

Tutkimusmatkailija pudotti kamppeet kainalostaan ja istuutui reppunsa päälle.

- Olisittehan te voinut sitten siitä kirjoittaa, ainakin viimeistään sanansaattajan pippurisanomassa. - Sitäpaitsi minun ja kolmen muun samassa tutkimusmatkatoimistossa työskentelevän reittisuunnitelmathan OVAT osa laajempaa matkaohjelmaa, jossa Ryhmämatkan jäsenten on tarkoitus saapua matkan kohteeseen eri suunnista ja näin tutkia maastoa reittejä ja nähtävyyksiä eri tahoilta!

- Oli miten oli, sanansaattaja sanoi reippaasti, olemme lakaisseet pöydän puhtaaksi. Kukaan ei pääse uusia reittejä tutkimaan. Pöytä on puhdas! Ja sillä siisti!

Ne kuusi tutkimusmatkailijaa kuulivat sitten Rahapussiporukan robotilta Lieveilmiö, että Rahapussiporukka oli tarkistuttanut tutkimusmatkareitit joillakin Matkaoppailla, - siis niillä, jotka ovat käyneet lyhyen ja tehokkaan matkaopaskurssin - ja jotka tottuneesti kaitsevat suuria laumoja katsomaan samoja nähtävyyksiä vuodesta vuoteen. Sen he osaavat varmaan hyvin.

Mutta ehkä he eivät tiedä, että Tutkimusmatkailija ei koskaan palaa samalle polulle. Eikä hän siis voi etukäteen tietää mitä hän tulee löytämään; muutenhan hän ei olisi Tutkimusmatkailija.

Ja niin Rahapussiporukka, pyyhkäistyään pöydän puhtaaksi kaikenkarvaisista tutkimusmatkareittisuunnitelmista, jäi tyytyväisenä odottelemaan Kevään Uutta Matkaopasta Vanhaan Tuttuun Maailmaan. Siitä ainakin tietää mitä rahoillaan saa!

Sadun löysi tomuiselta ullakolta Singa Sandelin 